- designed to conclusively test efficacy, have begun recruiting patients. Cardio3 BioSciences, based in Mont-Saint-Guibert, Belgium, is recruiting 480 patients with heart failure in parallel trials of its 'C-CURE' stem-cell therapy - a preparation of specially treated stem cells that are allegedly capable of developing into heart cells. And the European Commission is sponsoring a Europe-wide $€ 5$.9-million (US\$8.2-million) trial, called BAMI, which tests patient-derived stem cells prepared according to a standardized protocol. It is recruiting 3,000 patients who have recently had a heart attack. The principal investigators

\section{"I have a lot of hope for regenerative medicine, but our results make me fearful."}

of both studies say that the treatment has been shown to be safe and may be effective.

However, questions have been raised over an earlier trial of C-CURE. Last June, three months after Francis's study closed, the Journal of the American College of Cardiology (JACC) published an early-phase trial of C-CURE, which found "signs of benefit in chronic heart failure" ${ }^{4}$. Francis's team analysed it separately and identified dozens of discrepancies similar to those found in the BMJ study. He sent details to JACC, but claims that the paper's authors did not answer some of his more important concerns: for example, about an apparent change in the study's 'primary endpoint', a trial's main target, and an apparent inconsistency between patient data and the summary of the results.

Co-author Andre Terzic, a cardiologist at the Mayo Clinic in Rochester, Minnesota, denies that Francis's concerns were not addressed and stresses that his group's findings were peer-reviewed. He adds that the decision to drop the initial endpoint - to measure heartbeat strength by monitoring the movement of radioactive tracers through the heart - was made on the advice of the study's steering committee, which said that such efficacy need be assessed only in a phase III trial. The planned phase III trial has now been authorized by the US Food and Drug Administration and the European Medicines Agency, Terzic says.

Another co-author of the JACC paper, William Wijns of the Cardiovascular Centre Aalst in Belgium, who is a member of the Cardio3 BioSciences board, told Nature that he is "confident in the science supporting the technology and in the C-CURE clinical trial data". A few weeks after the JACC publication, Cardio3 BioSciences announced that it had raised $€ 23$ million for a phase III trial in a share offering.

BAMI principal investigator Anthony Mathur, of Queen Mary University of London, says that he wants to clarify definitively if there is hope for the treatment. He adds that the trial was built on "a clear signal of efficacy" in some early-phase trials using a standardized protocol that is publicly available.

Christine Mummery, a cardiac-stem-cell researcher at Leiden University Medical Centre in the Netherlands, says that injecting bone-marrow cells causes inflammation and the development of small blood vessels that might limit immediate damage during a subsequent heart attack. "But it is not clear this helps long-term recovery of the heart, and it does not provide a mechanism for improvement in heart failure," she adds.

Even without solid published evidence of efficacy, many companies are offering various commercial mesenchymal-stem-cell therapies to patients with heart disease. For example, the Okyanos Heart Institute in Freeport, the Bahamas, uses mesenchymal stem cells derived from a patient's fat tissue. Howard Walpole, its chief medical officer, was unavailable for comment, but writes on the company's website: "We strongly believe in the science and results we have seen with adult stem cell therapy for coronary artery disease." He adds that many heart patients "do not have the luxury of waiting many years for exhaustive research to be completed".

CardioCell, based in San Diego, California, uses its own standardized proprietary preparation of mesenchymal stem cells rather than a patient's own cells. The company's president and co-founder, Sergey Sikora, says the preparation is based on a method developed at a Moscow research institute in which the stem cells are kept in low oxygen to hone their ability to stimulate the growth of new blood vessels. CardioCell has also licensed the technology to a company called Altaco in Astana, Kazakhstan. Sikora says that CardioCell is currently not offering therapy ouside its own early-phase trials in heart attack and a type of heart failure in the United States, but Altaco has begun a phase III trial for heart attack.

Francis would like to see more evidence that the treatments work before they are exploited. "I have a lot of hope for regenerative medicine, but our results make me fearful," he says. "When the inevitable clinical advantages come, they may be ignored because these 15 years of unreliable data may have damaged credibility." -

1. Nowbar, A. N. et al. Br. Med. J. 348, g2688 (2014).

2. Laflamme, M. A. \& Murry, C. E. Nature $\mathbf{4 7 3 ,}$

426-335 (2011).

3. Bolli, R. et al. Lancet 378, 1847-1857 (2011).

4. Bartunek, J. et al. J. Am. Coll. Cardiol. 61, 2329-2338 (2013).

\title{
US biodefence facilities ramp up
}

\section{Government effort to produce vaccines on demand raises questions about cost and strategy.}

\section{BY SARA REARDON}

$\mathrm{T}$ The future of the US government's biodefence strategy sits in a warehouse in rural Texas. A dozen gleaming-white trailers, each about the length of a bus, hold equipment for producing millions of doses of medical countermeasures against some of the world's deadliest threats. These mobile clean rooms can be configured to manufacture vaccines against pandemic influenza or antidotes to biological, chemical or radioactive agents. Each room can be unplugged from the pipes that supply sterile air and cellculture media, pushed across the warehouse, and connected to a new production line - ready in days to make a different product.

The US\$286-million site at Texas A\&M

University in Bryan is one of three new biodefence centres created by the US Department of Health and Human Services (HHS). It will start making its first vaccine this summer. Once completed in 2017, it will be able to make 50 million doses of flu vaccine in just four months - capacity that biosecurity experts say the United States needs to prepare for future pandemics.

Yet some worry that the Texas lab and its counterparts form a system that is too disjointed to deliver as promised. Others argue against expanding capacity to produce countermeasures to biological or chemical threats, in part because few effective antidotes exist. "They're going to have a lot of challenges," says Keith Wells, a consultant at BioProcess Technology Consultants in Woburn, Massachusetts.

The \$440-million HHS programme, set up in 2012, includes three Centers for Innovation in Advanced Development and Manufacturing (CIADMs): the Texas site; one in Holly Springs, North Carolina, being built by pharmaceutical giant Novartis of Basel, Switzerland; and a facility in Baltimore, Maryland, to be run by biotechnology firm Emergent BioSolutions. Over the next 25 years, the government expects to spend as much as $\$ 2$ billion on medical countermeasures from the Texas site alone, and up to $\$ 23$ million per year to 


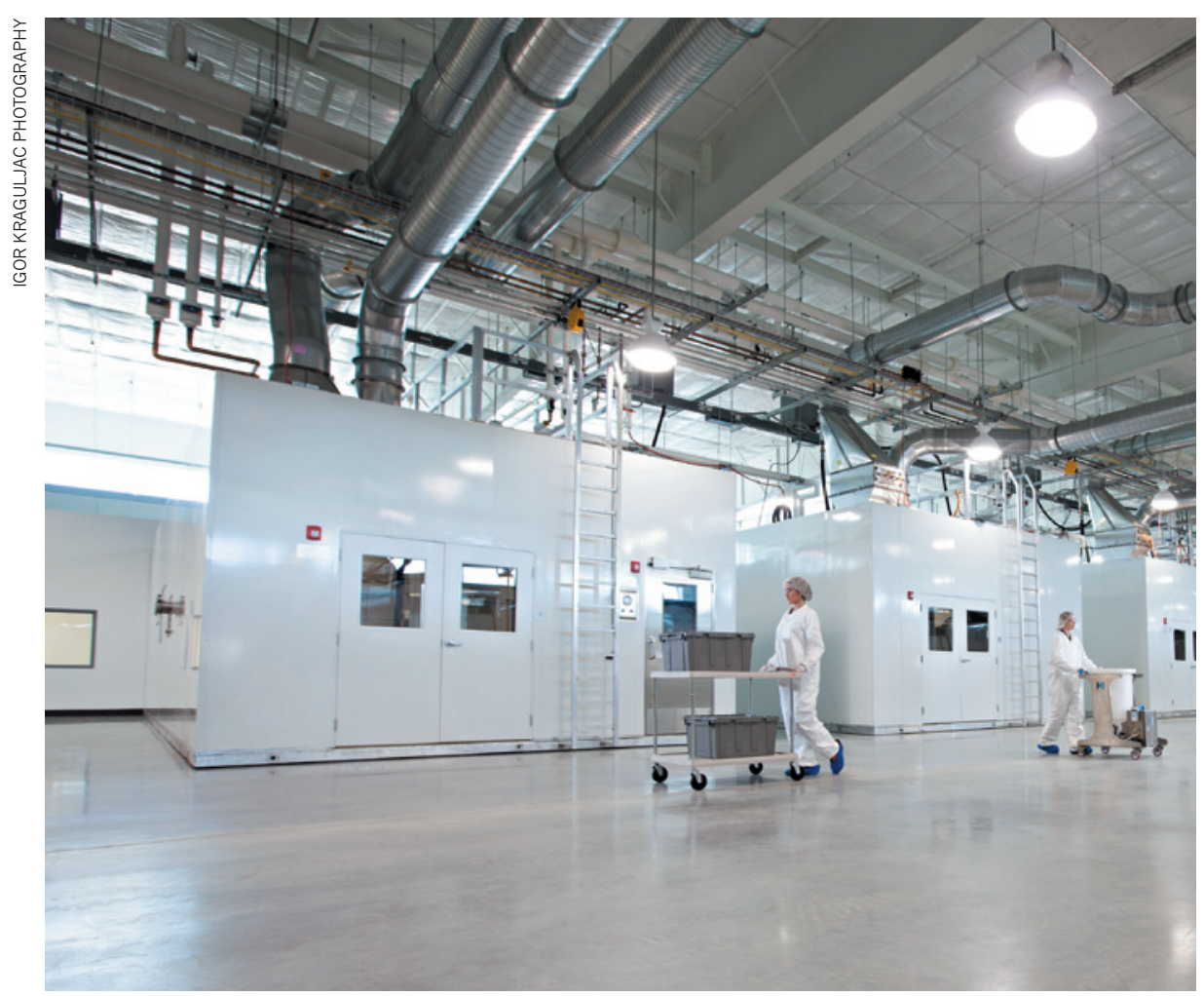

Mobile clean rooms for manufacturing medical antidotes and vaccines at Texas A\&M University in Bryan.

stockpile flu vaccines - a cost that could skyrocket if a pandemic strikes.

Gerald Parker, director of the Texas A\&M centre, says that the programme's flexible manufacturing is crucial for US biosecurity. "We need to be prepared for all hazards, not just the last one that hit us," he says. Other threats could emerge, such as the coronavirus behind Middle East respiratory syndrome, which surfaced in Saudi Arabia in 2012, or the Ebola virus outbreak currently spreading in West Africa. If one of these viruses sparks a pandemic and a vaccine can be developed, the CIADMs will need to produce it quickly and prepare it for the market.

Such capacity is long overdue, and experts contend that it may be possible to achieve only with government funding. Many large companies have stopped developing vaccines because the public often views them with scepticism, says Robert Kadlec, a former White House director for biodefence policy. And small companies often lack the experience to bring such treatments to market.

Government initiatives such as the CIADMs counter this trend by creating an artificial market for specialized vaccines and antidotes, says Amesh Adalja, a physician at the University of Pittsburgh Medical Center in Pennsylvania who studies biosecurity issues. But incentives are not always effective: on 22 April, Novartis announced the sale of its vaccine programme to drug giant GlaxoSmithKline in London. It also plans to sell its government-funded CIADM in North Carolina.

The US biodefence programme also faces the practical challenge of developing and adopting faster methods to make vaccines. Conventional flu-vaccine production, in which each dose is grown in a chicken egg, is notoriously slow; newer methods that culture vaccines in cells are much faster. In 2012, Novartis' Flucelvax became the first cell-based flu vaccine to gain approval from the US Food and Drug Administration. GlaxoSmithKline and Novartis have developed ways to grow vaccine particles in bird and mammal cells, respectively. And Emergent has partnered with Vaxinnate, a small company in Cranbury, New Jersey, that is working to induce Escherichia coli bacteria to make proteins that will raise an immune response against influenza or other agents. "As we move away from eggs, it makes sense not to put our cell cultures in one basket," says Richard Ebright, a molecular biologist at Rutgers University in Piscataway, New Jersey.

\section{STRATEGIC STOCKPILE}

The three CIADMs are also working to develop countermeasures against bioterror agents such as smallpox that could be produced on demand. Under the current strategy, "we just hope the bad guys attack us with what we stockpiled", says Brett Giroir, executive vice-president of the Texas A\&M Health Science Center, who says that the CIADMs could replenish the existing strategic national stockpile and even expand it over time. The centres' capacity will be put to the test later this year, when the government will place its first orders for medical countermeasures, according to Robin Robinson, director of the Biomedical Advanced Research and Development Authority in Washington DC, which will oversee the centres.

But some question whether these countermeasures, such as advanced smallpox vaccines, are mature enough to be manufactured and stockpiled - or whether they are even needed. The chance of being attacked with a chemical or biological agent, and then being able to use a vaccine to respond to it effectively, is low, says Ebright.

Others say that the United States does not need multiple biodefence centres, pointing to a 2008 report prepared for the Defense Advanced Research Projects Agency, which recommended the creation of a single development and manufacturing facility to serve both the military and civilians. "Rather than one good operation that meets the government's needs, we got three operations that spread the money around," says Philip Russell, a retired major general and former leader of the US Army's medical research command. The HHS centres' supporters say that having three sites creates flexibility and leaves backups in case a site is contaminated or attacked.

Despite concerns about duplicated effort, the US Department of Defense (DoD) began building its own \$136-million biodefence facility in 2013 in Alachua, Florida. Once the site is completed in 2015, the military expects to spend more than $\$ 20$ million on it each year. Kendall Hoyt, a biodefence policy specialist at Dartmouth College in Hanover, New Hampshire, says that the separate effort makes sense: the military requires relatively small amounts

\section{"We need to be prepared for all hazards, not just the last one that hit us."} of a variety of countermeasures, whereas the HHS needs large amounts of a few products. Moreover, the military needs to respond quickly to the wider range of threats that it faces, says James Petro, acting deputy assistant secretary of defence for chemical and biological defence. Such concerns "led us to recognize that it was important we had a facility that was under DoD control", he adds.

But Petro says that the separation from the HHS is only temporary. "The intent has been and continues to be that once all the centres are up and running, they'll be operating together as a consortium," he says.

Either way, because they are the first centres of their kind, the HHS facilities have their work cut out for them, says Leonard Cole, a bioterrorism specialist at Rutgers in Newark, New Jersey. A 31 March report from the US Government Accountability Office concluded that it was still too early to tell whether the billions of dollars that stand to be funnelled into the HHS project are a good investment. Nevertheless, "if there's the kind of pay-off we'd hope to come from this, it's worth every nickel", says Cole. 